\title{
Praktik Sosial Goenawan Mohamad di Arena Sastra Indonesia pada Tahun 1990-an: Kajian Sosiologi Anthony Giddens
}

\author{
Aprilia Ciptaning Maharani dan Dwi Susanto \\ Fakultas Ilmu Budaya, Universitas Sebelas Maret \\ apriliaciptaningm@gmail.com
}

\begin{abstract}
The purpose of this study is to find out how GM's social practices as agents in the Indonesian literary arena in the 1990s, and the structural responses to these social practices. This research is qualitative. The material object is GM's social practice in the Indonesian literary arena in the 1990s, while the formal object is the arena structure's response to the action. Data analysis was performed by chronological mapping accompanied by decomposition that referred to Anthony Giddens's sociological theories. Based on research that has been done, the results show that GM runs social practices by occupying several arena structures, including Horison, AJ and DKJ, Tempo through Caping, and KUK. The structural response to these actions was manifested in several conflicts, contradictions and acceptances that helped to bolster the existence of GM's literacy in the Indonesian literary arena from the beginning to the 1990s.
\end{abstract}

Keywords: Goenawan Mohamad; agent; capital; literary arena; sociology Anthony Giddens.

\section{Intisari}

Penelitian ini bertujuan untuk mengetahui bagaimana praktik sosial GM sebagai agen di arena sastra Indonesia pada tahun 1990-an, dan respons struktur terhadap praktik sosial tersebut. Penelitian ini bersifat kualitatif. Objek material berupa praktik sosial GM di arena sastra Indonesia pada tahun 1990-an, sedangkan objek formal berupa respons struktur arena terhadap tindakan tersebut. Data penelitian ini meliputi seluruh informasi yang relevan dengan GM berikut struktur sosial yang melingkupinya di arena sastra Indonesia sejak awal hingga era 1990an. Analisis data dilakukan dengan pemetaan secara kronologis disertai penguraian yang merujuk pada konsep-konsep teori sosiologi Anthony Giddens. Berdasarkan penelitian yang telah dilakukan, didapatkan hasil bahwa GM menjalankan praktik sosial dengan menempati beberapa struktur arena, di antaranya Horison, AJ dan DKJ, Tempo melalui Caping, dan KUK. Rangkaian aktivitas yang dilakukan GM saling terkait dan berhubungan satu sama lain. Respons struktur terhadap tindakan tersebut terwujud pada beberapa konflik, kontradiksi, maupun penerimaan yang ikut melambungkan eksistensi kesastrawanan GM di arena sastra Indonesia sejak awal hingga tahun 1990-an.

Kata Kunci: Goenawan Mohamad; agen; modal; arena sastra; sosiologi Anthony Giddens.

\section{Pendahuluan}

Agen dalam konteks sastra dapat berupa individu, organisasi, lembaga, dan kumpulan individu yang terikat oleh satu cita-cita, pemikiran, ideologi, dan tujuan yang sama baik secara formal maupun yang bukan formal (Susanto, 2015:10). Masing-masing dari mereka membawa kepentingan dan menjalankan berbagai strategi dalam rangka menduduki posisi tertentu dalam arenanya. Usaha tersebut diwujudkan dalam bentuk praktik sosial, salah satunya oleh Goenawan Mohamad (GM) sebagai sastrawan yang merupakan agen di arena sastra Indonesia. 
Kiprahnya dalam dunia seni diperhitungkan karena selain sebagai sastrawan yang menghasilkan berbagai karya, ia juga seorang jurnalis di beberapa surat kabar, salah satunya yang paling terkenal yaitu Tempo. Keterlibatan GM di arena sastra Indonesia sudah dimulai sejak tahun 1960-an di masa pemerintahan Demokrasi Terpimpin di mana GM menjadi salah satu tokoh yang ikut menandatangani naskah Manifes Kebudayaan (Manikebu), sebuah pernyataan sikap berkesenian yang dinyatakan terlarang oleh Presiden Soekarno saat itu.

Aktivitas GM pada periode ini juga turut andil dalam posisi kepengurusan di Dewan Kesenian Jakarta (DKJ) sebagai anggota di komite sastra selama dua periode (1968-1976). DKJ sendiri merupakan sebuah lembaga resmi mitra kerja gubernur DKI Jakarta yang bertugas untuk merumuskan kebijakan serta merencanakan berbagai program guna mendukung kegiatan dan pengembangan kehidupan di wilayah Jakarta. Anggota DKJ dipilih dari para seniman dan pemikir seni budaya yang kompeten di bidangnya.

GM pun menjadi salah satu sastrawan yang ikut menempati posisi dalam kepengurusan di Akademi Jakarta (AJ), sebuah lembaga kehormatan di bidang kesenian yang menjadi semacam tempat bertanya dalam pengelolaan kebudayaan. Keanggotaan AJ dipilih dari para seniman atau budayawan yang telah berprestasi di bidang masing-masing (Mahanani, 2017:47).

Produktivitas menulis GM dalam berkarya, menjadi perhatian masyarakat umum khususnya para sastrawan yang lebih dulu berkecimpung di arena sastra Indonesia. Tulisantulisannya yang dimuat di media massa menjadi salah satu pembuka jalan untuk bergabung dalam redaksi surat kabar atau majalah, salah satunya Horison. Pada tahun 1970-an, Horison dianggap sebagai kiblat sastra Indonesia mutakhir yang meneruskan generasi majalah-majalah sastra sebelumnya, seperti Kisah, Sastra, dan Tjerita (Sumardjo, 1979:148-153). Selama bergabung, posisi GM mengalami peningkatan yang semula di redaksi, menjadi dewan penasihat, hingga penyantun.

Perjalanan aktivitas kesenian GM semakin berkembang, mulai dari pencapaian yang berupa penghargaan hingga sejumlah konflik serta kontradiksi dengan sastrawan lain. Pada tahun 1970-an, muncul kritik terhadap GM terkait aktivitasnya sebagai kritikus sastra dan penyair dalam Polemik Kritik Sastra dan Pengadilan Puisi (Pradopo, 2017:208). Selain itu, pada tahun 1994, permasalahan lain juga menimpa GM di Horison. Perdebatannya dengan salah satu pendiri yakni Mochtar Lubis, menyebabkan majalah sastra tersebut terpecah menjadi dua, yakni Horison lama pimpinan Mochtar Lubis dan Horison baru yang diterbitkan sendiri oleh GM. Hal itu dipicu oleh beberapa sebab, salah satunya berkaitan dengan pengelolaan PT. Grafiti Perspenerbit Tempo yang juga dikelola oleh GM. 
Selain di Horison, konflik yang dihadapi GM juga datang dari Tempo. Setelah sebelumnya pernah dibredel pada tahun 1971, majalah yang dipimpin GM tersebut kembali dicabut surat izinnya oleh penguasa Orde Baru pada tahun 1994. Hal itu berdampak pada rubrik Catatan Pinggir (Caping) — esai GM di dalam Tempo-yang ikut tidak terbit (Kompas, 1995). Atas sejumlah praktik sosial tersebut, GM tergolong tokoh yang fenomenal. Sebagai sastrawan, ia tidak hanya berkiprah dengan menghasilkan karya sastra, tetapi juga terlibat dalam berbagai polemik, baik yang berhubungan dengan kebijakan pemerintah maupun konflik dengan seniman lain.

Menuju penghujung masa kepemimpinan Orde Baru, pada tahun 1995 GM bersama dengan sejumlah tokoh di antaranya pemimpin redaksi Suara Pembaruan (Aristides Katoppo), peneliti LIPI (Mochtar Pabottinggi), jurnalis senior Radio Mara (Mohamad Sunjaya), dan praktisi komunikasi UGM (Ashadi Siregar) mendirikan Komunitas Utan Kayu (KUK) sebagai bentuk kritik atas perlawanannya terhadap rezim penguasa yang otoriter. KUK merupakan pusat kegiatan bagi para aktivis, seniman, maupun cendekiawan dalam mengadakan berbagai diskusi lintas pemikiran. Di bidang kesenian, KUK melahirkan Galeri Lontar, Jurnal Kebudayaan Kalam, dan Teater Utan Kayu (TUK).

Hubungan GM dengan arenanya bersifat dualitas (timbal balik). GM dapat melahirkan tindakannya atas kerja sama struktur yang membentuk sarana sekaligus keterulangan praktik sosial. Maka, kekuasaan GM dalam arena sastra bukan merupakan suatu totalitas, melainkan dominasi melalui modal-modal yang dimilikinya.

Penelitian sebelumnya lebih banyak menganalisis secara tekstual karya-karya GM untuk mencari makna dan pemikiran GM sebagai sastrawan. Pertama, Anwar Effendi (2005) membahas mengenai gambaran perjalanan kepenyairan GM. Aktivitas menulis puisi yang dimulai sejak awal tahun 1960-an, GM memilih eksistensi manusia sebagai tema utama. Kedua, tentang pengaruh warna budaya dan mitologi Jawa dalam karya-karya GM pernah dilakukan oleh Burhan Nurgiyantoro (1999). Penelitian tersebut dapat disimpulkan bahwa karya-karya GM dipengaruhi oleh budaya Jawa berupa unsur-unsur mitologi yang berasal dari tanah air, meliputi cerita wayang, Panji Menak, Anglingdarma, dan Babad Tanah Jawi. Mitologi diperlakukan GM sebagai sebuah sikap penerimaan yang menunjukkan fakta secara apa adanya.

Berdasarkan penelitan di atas, peneliti melakukan penelitian yang berbeda dengan penelitian sebelumnya mengenai GM. Penelitian ini termasuk ke dalam sosiologi sastra dengan berobjekkan GM berikut struktur sosial yang ditempatinya. Penelitian ini membahas bagaimana GM menjalankan praktik sosial sebagai agen di arena sastra Indonesia pada tahun 1990-an serta respons struktur arena atas tindakan tersebut. 
Salah satu tema sentral yang menjadi pokok pemikiran Giddens, yakni hubungan antara struktur (structure) dengan pelaku (agency). Keduanya memiliki relasi dualitas, atau dengan kata lain keduanya saling mengandaikan. Struktur adalah aturan (rules) dan sumber daya (resources) yang terbentuk sekaligus membentuk praktik sosial. Dualitas struktur dan pelaku terletak dalam proses di mana struktur sosial bukan hanya merupakan hasil (outcome), melainkan juga sarana (medium) atas tindakan tersebut (Priyono 2016:18).

Praktik sosial yang dimaksud dalam struktur bisa diterapkan pada berbagai situasi dan kondisi. Praktik ini dapat berupa kebiasaan yang berulang dan terpola dalam lintas ruang dan waktu, meskipun dilakukan dengan bentuk dan cara yang berbeda-beda. Tindakan yang berulang memungkinkan terjadinya praktik sosial baru atau reproduksi.

Namun, di sisi lain agen sebagai pelaku mempunyai kemampuan untuk introspeksi dan mawas diri (reflexive monitoring of conduct). Perubahan terjadi ketika kapasitas memonitor (mengambil jarak) ini meluas sehingga berlangsung "derutinisasi". Derutinisasi menyangkut gejala di mana skemata yang selama ini menjadi aturan dan sumber daya tindakan tidak lagi memadai untuk dipakai sebagai prinsip pemaknaan dan pengorganisasian berbagai praktik sosial yang sedang berlangsung atau yang sedang diperjuangkan agar menjadi praktik sosial baru (Priyono 2016:30). Tujuan teori strukturasi adalah menjelaskan hubungan saling memengaruhi antara agen dengan struktur.

\section{Metode Penelitian}

Jenis penelitian ini adalah penelitian kualitatif. Objek material yang digunakan adalah praktik sosial Goenawan Mohamad (GM) di arena sastra Indonesia pada tahun 1990-an, sedangkan objek formal meliputi respons struktur terhadap tindakan GM di arena sastra Indonesia pada era tersebut. Data primer dalam penelitian ini adalah aktivitas GM sebagai agen di dalam struktur arena sastra yang melingkupinya, serta tulisan mengenai arena sastra Indonesia sejak tahun 1960-1990-an. Data sekunder dalam penelitian ini meliputi biografi dan latar sosial GM serta kondisi arena sastra Indonesia pada tahun 1990-an. Sumber data dalam penelitian ini berupa sumber data primer dan sekunder. Sumber data primer diperoleh dari arsip Dewan Kesenian Jakarta (DKJ), Pusat Dokumentasi Sastra H.B. Jassin (PDS H.B. Jassin), Perpustakaan Nasional Republik Indonesia (PNRI), dan Perpustakaan Salihara. Sumber data sekunder diperoleh dari studi pustaka berupa artikel dan penelitian yang pernah dilakukan tentang GM.

Teknik pengumpulan data pada penelitian ini dilakukan dengan cara mencatat dan studi kepustakaan. Analisis data dimulai dengan menguraikan arena sastra Indonesia secara umum sejak awal hingga tahun 1990-an sekaligus menyinggung GM sebagai sastrawan yang 
menempati posisi agen di dalamnya. Pembahasan dilanjutkan dengan menganalisis genetika sosial GM yang selanjutnya difokuskan terhadap bentuk praktik sosial GM. Setelah itu, akan diketahui respons struktur yang ditempati GM di arena sastra Indonesia sehingga dapat diuraikan hubungan keduanya yang timbal balik (dualitas).

\section{Hasil dan Pembahasan}

\section{Perjalanan Arena Sastra Indonesia}

Seniman yang hidup di suatu tempat dan pada waktu yang sama mempunyai persamaanpersamaan yang membawa pengaruh bagi masyarakat dan alam pikiran zamannya. Persamaanpersamaan inilah yang kemudian dijadikan petunjuk dan landasan bagi para penelaah kesusastraan dengan menyebut suatu kelompok sebagai angkatan atau periode. Berbagai persamaan tersebut akan terlihat dalam pandangannya tentang kesenian dan kesusastraan lewat buah tangannya (Rosidi, 1985:11-12).

Sudah banyak terdapat perdebatan mengenai kapan kesusastraan Indonesia lahir, tetapi sejarah tersebut tidak dapat dilepaskan dari pengaruh kolonialisme di masa lalu. Pada tahun 1908, pemerintahan Belanda yang berkuasa atas tanah air mendirikan Komisi Bacaan Rakyat yang pada tahun 1917, berubah namanya menjadi Kantor Bacaan Rakyat atau dikenal dengan Balai Pustaka. Melalui konsep-konsep estetika tertentu, seperti penggunaan bahasa dan isi cerita, teks-teks di luar kanon atau tradisi Balai Pustaka (kolonial) dinyatakan sebagai teks atau bacaan terlarang dan liar (Sulton dalam Susanto dan Wati, 2010:40-52). Dalam praktiknya ini, pemerintah kolonial pada dasarnya melakukan pembatasan terhadap karya sastra. Terbitan dari Balai Pustaka, antara lain Darah Muda (1927), Asmara Jaya (1928) karya Adinegoro, dan Salah Asuhan (1928) karya Abdul Muis. Sanusi Pane yang pernah menjabat sebagai redaktur di Balai Pustaka turut muncul dengan karya-karyanya, antara lain Kertajaya (1932), Sandhyakala ning Majapahit (1933), dan Manusia Baru (1940) (Rosidi, 1968:30).

Memasuki periode 1933-1942, lahir majalah bernama Poedjangga Baroe yang didirikan oleh Armin Pane, Amir Hamzah, dan Sutan Takdir Alisjahbana (STA) (Rosidi 1968). Perkembangan tema yang berbeda juga diperlihatkan oleh periode ini. Kolektivitas yang sebelumnya mendominasi, kemudian berangsur-angsur berubah ke arah individualisme. Roman yang terkenal pada masa ini, yaitu Layar Terkembang (1936) karya STA dan Belenggu (1940) karya Armijn Pane.

Memasuki Angkatan '45, periode ini ditandai dengan kemunculan Chairil Anwar pada tahun 1942 yang dianggap telah memberikan sesuatu yang baru bagi panggung sastra Indonesia. Sejumlah pengarang yang tampil adalah Pramoedya Ananta Toer dengan karya puncaknya 
Percikan Revolusi (1950), dan Mereka yang Dilumpuhkan (1951); serta Achdiat Karta Mihardja dengan Atheis (1949).

Memasuki dasawarsa tahun 1950-an, kesusastraan Indonesia berada dalam situasi yang amat semarak. Selain tentang kisah peperangan, karya sastra muncul dengan semangat kedaerahan dan nafas filsafat eksistensialisme. Sitor Situmorang, Nasjah Djamin, dan Iwan Simatupang adalah beberapa nama yang bersemangat memasukkan filsafat eksistensialisme ke dalam karya-karyanya. Selain karya sastra yang beragam dan semarak, jagat kesenian pada masa ini ditandai pula dengan lahirnya sebuah Lembaga Kebudayaan Rakyat (Lekra) pada tanggal 17 Agustus 1950.

Awal tahun 1960-an, muncul sebuah naskah pernyataan yang dikenal dengan Manifes Kebudayaan (Manikebu). Mereka menolak konsep kesenian Lekra, yakni "politik adalah panglima" dengan mengusung humanisme universal yang lebih menekankan kebebasan berpikir dan berekspresi tanpa adanya kekangan politik (Sambodja, 2010:23). GM termasuk salah satu tokoh yang ikut menandatangani naskah di samping sembilan belas nama pencetus lain seperti, H.B. Jassin, Trisno Sumardjo, Wiratmo Soekita, dan lain-lain. Akhirnya, perseteruan antara kelompok Lekra dengan Manikebu menuai puncaknya pada tahun 1964 di mana Presiden Soekarno mengambil tindakan dengan menandatangani surat yang berisi pelarangan terhadap Manikebu.

Periode 1960-an merupakan tahun-tahun yang diwarnai pergolakan sosial dan politik di Indonesia. Di tengah-tengah situasi tersebut, terbit majalah Sastra (1961) dan Horison (1966) yang merupakan media para pengarang kalangan "Angkatan Manifes" (Siregar dalam Kratz, 2000:726). Kedua majalah sastra tersebut berhasil melahirkan sejumlah kritikus sastra. Selain Arif Budiman, Pradopo (2017) mengatakan bahwa GM adalah salah satu kritikus yang paling menonjol. Para kritikus sastra berlomba-lomba mengemukakan gagasannya dalam setiap tulisan yang muncul. Bahkan, pada akhir tahun 1960-an muncul perdebatan yang dikenal dengan Polemik Kritik Sastra antara golongan Ganzheit dengan kritik sastra Akademik.

Selepas tahun 1965, seniman Indonesia seolah-olah memperoleh saluran kebebasan lebih luas. Kebebasan berekspresi yang dijanjikan oleh Orde Baru salah satunya diwujudkan dengan hadirnya Pusat Kesenian Jakarta Taman Ismail Marzuki (PKJ TIM) dan dibentuknya Dewan Kesenian Jakarta (DKJ) sebagai lembaga yang bertanggung jawab atas pelaksanaan sejumlah agenda budaya di PKJ TIM. DKJ sebagai pengelola berisi panitia formatur Akademi Jakarta (AJ). Di antara pengurus AJ, GM termasuk salah satu yang menjadi panitia formatur pertama.

Beralih ke tahun 1967 dan terutama di awal tahun 1970-an, kemunculan karya sastra memperlihatkan semangat kebebasan. Bahkan, di antaranya tidak sedikit novel-novel yang 
mengejawantahkan ke dalam bentuk karya eksperimental. Ciri-ciri yang mencolok dari eksperimentasi dalam novel dapat diwakili oleh karya-karya Iwan Simatupang (Merahnya Merah, 1968; Ziarah, 1969; Kering, 1972; dan Koong, 1975) dan Putu Wijaya (Bila Malam Bertambah Malam, 1971; Telegram, 1972; Pabrik, 1976; Stasiun, 1977; Lho, 1982). Pada masa ini, estetika kepenyairan lain juga ditampilkan oleh Sutardji Calzoum Bahri dengan mendobrak dunia perpuisian melalui puisi mantra. Kredonya yang menolak makna dalam kata, Sutardji memilih mengandalkan kemerduan bunyi daripada berpanjang-panjang dalam menulis kata.

Perkembangan selanjutnya adalah kelahiran Angkatan 80 yang berisi mayoritas karya sastra lokalitas. Pengungkapan tema tersebut salah satunya disampaikan dalam karya yang mengusung jagat Jawa. Ahmad Tohari muncul dengan Ronggeng Dukuh Paruk (1982) membawa semangat yang kental akan sebuah tradisi melalui penceritaannya yang detail.

Memasuki era 90-an, muncul gebrakan melalui terbentuknya komunitas yang didirikan sebagai alternatif gerakan, antara lain Forum Lingkar Pena (FLP), Revitalisasi Sastra Pedalaman (RSP), dan Komunitas Utan Kayu (KUK) yang terdapat GM sebagai ikon. GM di dalam KUK mengusung ideologinya melalui berbagai argumen dan estetika. Salah satu alat untuk mencermati kode estetikanya dapat dilihat dari sejumlah karya dan berbagai kegiatan yang diselenggarakan.

Demikian uraian secara umum mengenai sejarah dan perjalanan arena kesusastraan Indonesia dari awal kemunculan sampai era 90-an. Dari penjelasan tersebut, dapat diketahui bahwa GM dalam menjalankan suatu praktik sosial, telah berkiprah sejak periode 60 -an dengan menempati beberapa struktur arena sastra antara lain, Horison, AJ dan DKJ, Tempo lewat Caping, serta KUK. Sejumlah tempat tersebut menjadi arena yang digunakan untuk memproduksi sekaligus mereproduksi sumber daya sebagai modal dalam bertarung di arena sastra Indonesia.

\section{Genetika Sosial Goenawan Mohamad}

Goenawan Soesatyo Mohamad (GM) lahir pada tanggal 29 Juli 1941 di Karangasem, Batang, Jawa Tengah. Sejak kecil, ia sudah menjadi yatim dan tinggal bersama ibu dan kakaknya dengan berpindah-pindah tempat. Pendidikan Sekolah Dasar (SD) hingga Sekolah Menengah Atas (SMA) dijalaninya di kota-kota kecil Jawa Tengah, antara lain Parakan, Wonosobo, dan Pekalongan.

Akhir tahun 1959, GM merantau ke Jakarta dan mulai mematangkan keahliannya menulis yang sudah dimulai sejak remaja. Meskipun ia meneruskan pendidikan S1 di Fakultas 
Psikologi Universitas Indonesia — tidak tamat-, tetapi ia sering menulis sejumlah puisi dan diterbitkan di Harian Abadi. Sejak saat itu, kepenyairan GM mulai diakui di arena sastra.

Kemampuan menulis GM semakin tersalurkan tatkala ia mulai bekerja di bidang jurnalistik dengan bergabung di bagian redaksi surat kabar. Menjadi reporter sejak 1967 di Harian KAMI, kemudian majalah Ekspress pada tahun 1971, setelah GM kembali dari belajar di College d'Europe, Brugee, Belgia, ia melanjutkan keinginannya untuk membangun surat kabar sendiri. Bersama rekan-rekannya, Tempo didirikan dan terbit kali pertama pada 6 Juni 1971 dengan format berita yang bercerita atau berkisah.

Selain berbagai karya sastra dan penghargaan yang diperolehnya, GM yang telah berkiprah di arena sastra sejak tahun 1960-an pernah terlibat dalam beberapa pergulatan penting. Polemik Kebudayaan Lekra versus Manikebu pada era itu ikut membawa nama GM menjadi sastrawan yang berpengaruh. Keikutsertaan tersebut memunculkan julukan tersendiri bagi sastrawan angkatan ini sebagai Angkatan '66 atau Angkatan Manikebu.

Kembalinya kebebasan para sastrawan angkatan '66 disambut salah satunya oleh kemunculan majalah sastra Horison yang diisi oleh mayoritas nama-nama sastrawan simpatisan Manikebu. Banyaknya penulis besar yang keluar dari sana ikut memengaruhi penilaian masyarakat terhadap sastrawan dan karya-karyanya di arena sastra Indonesia. Besarnya pengaruh Horison pada masa itu menyebabkan munculnya anggapan bahwa sastrawan di kelompok ini telah mendominasi arena sastra.

Pergantian Orde Lama menjadi Orde Baru membawa pengaruh tersendiri khususnya bagi udara kesenian Ibu kota. Terbentuknya PKJ TIM dan DKJ pada tanggal 7 Juni 1968 yang disahkan oleh Gubernur DKI Jakarta saat itu, Ali Sadikin, dinilai telah mendukung pesatnya perkembangan seni. TIM segera menjadi pusat kesenian yang marak dengan karya-karya eksperimentasi. DKJ sebagai lembaga yang diberi tanggung jawab untuk mengelola segala kegiatan di sana, diisi oleh para seniman Manikebu, tidak terkecuali GM yang mengusung konsep humanisme universal. GM menduduki panitia formatur pertama AJ yang memiliki wewenang untuk mempertimbangkan dan mengangkat pengurus harian di DKJ.

Julukan man of action dan man of talk pun disematkan kepada GM berkat kiprahnya selama ini. Di samping beraktivitas sebagai sastrawan, GM juga sempat bersinggungan dengan politik di masa Orde Baru. Aktivitas tersebut tidak dapat dipungkiri merupakan salah satu sikap perlawanan yang ditujukan GM terhadap pemerintahan Orde Baru yang dikenal diktator.

Perbedaan pendapat antara GM dengan pemerintahan kala itu tidak terbatas di sana. Peristiwa pembredelan tiga surat kabar (Editor, Detik, dan Tempo) di tahun 1994 ikut menjadi konflik yang mewarnai kehidupan sosial GM. Pembredelan yang pernah dialami Tempo pada 
tahun 1982 dan 1994 menyebabkan GM dan kalangan jurnalis geram dan berupaya melancarkan sebuah protes melalui inisiatif untuk mendirikan Aliansi Jurnalis Independen (AJI) sebagai bentuk perlawanan.

Bersamaan dengan lahirnya AJI, GM dan kawan-kawan mendirikan pula Institut Studi Arus Informasi (ISAI) yang ikut mempelopori munculnya Radio 68H, Galeri Lontar, Teater Utan Kayu (TUK), Jurnal Kebudayaan Kalam, dan Jaringan Islam Liberal (JIL) yang kemudian dikenal sebagai Komunitas Utan Kayu (KUK). Di tempat inilah, GM dianggap sebagai tokoh ikon yang kemudian mengembangkan lebih luas lagi karier kesenimanannya. Hal ini sesuai dengan konsep agen yang dikatakan oleh Giddens bahwa agen memproduksi perilaku secara bervariasi, lalu penyebarannya memunculkan berbagai tingkat kemampuan untuk bertindak pada ruang-ruang tertentu (Priyono 2016:25).

\section{Praktik Sosial Goenawan Mohamad di Arena Sastra Indonesia}

Goenawan Mohamad sebagai Sastrawan Horison

Salah satu praktik sosial GM di arena sastra dapat dilihat melalui hubungannya dengan Horison. Sebelum kemuculannya di Horison, sebenarnya tulisan GM sudah sering muncul di media massa kala itu. Namun, ia semakin disoroti ketika mendapatkan penghargaan dari majalah Sastra dua kali berturut-turut pada tahun 1962 dan 1963. Menyusul kemudian, pada tahun 1969, esai GM yang terbit pertama kali di Horison berjudul Seks, Sastra, Kita mendapat Hadiah Sastra dari majalah tersebut (Wibowo 2012, diakses tanggal 31 Juli 2019).

Kecemerlangan GM di Horison semakin ditunjukkan oleh tulisan-tulisannya yang mengulas karya sastra. Hal itu mendatangkan penilaian dan pengakuan dari kalangan seniman yang menyebut GM sebagai kritikus sastra. Di samping itu, kedudukan GM sebagai pengurus otomatis ikut menempatkan posisinya sebagai kurator. Tulisan-tulisan yang masuk pun disaring dan disesuaikan dengan estetika Horison yang tidak lain merupakan estetika para sastrawan di dalamnya. Namun, di sisi lain terdapat tindakan GM yang "tidak tampak", tetapi justru paling menonjol, yakni adanya upaya penyebaran estetika melalui serangkaian aktivitasnya di arena sastra yang selalu mendapat perhatian oleh Horison. Sejumlah agenda kesastrawanan GM tidak pernah luput untuk diberitakan dan dimuat dalam majalah tersebut.

Kepengurusan Goenawan Mohamad di AJ dan DKJ

GM menjadi salah satu nama yang terpilih sebagai pengurus AJ di antara seniman lain seperti Mochtar Lubis, Arif Budiman, Ajip Rosidi, H.B. Jassin, dan lain-lain (Yudiono K.S dalam Sulistyo, 2018:14). Mereka dianggap sebagai seniman yang mumpuni dan telah memiliki banyak pengalaman dalam kesenian Indonesia, khususnya bidang kesusastraan. GM sebagai tim 
formatur AJ ikut merangkap posisi sebagai anggota DPH selama dua periode berturut-turut (1968-1971 dan 1971-1972). Namun, praktik sosial GM tidak berhenti sebatas pada masa kepengurusannya. Berbagai tindakan GM terhadap penunjukkannya yang berturut-turut sebagai dewan juri sayembara oleh Komite Sastra, maupun menjadi perwakilan seniman dari DKJ atas beberapa agenda kesenian lainnya, merupakan rangkaian aktivitas yang menonjolkan sosoknya sebagai tokoh sentral. Di samping itu, GM juga menjalankan peranan penting yang berhubungan dengan modal ekonomi DKJ, yakni melalui Tempo yang secara tidak langsung menjadi salah satu penyumbang dana bagi DKJ.

Keseluruhan tindakan GM di AJ dan DKJ tersebut telah menunjukkan produksi aktivitas yang tidak sebatas membentuk maupun menghasilkan modal simbolik dan sosial kultural, melainkan juga memainkan modal ekonomi. Meskipun GM melalui Tempo dapat dikatakan sebagai penyumbang atas DKJ, tetapi sesungguhnya modal ekonomi tersebut digunakan secara melingkar dan berputar kembali pada GM sehingga keduanya memperoleh manfaat yang saling menguntungkan.

\section{Goenawan Mohamad dan Catatan Pinggir Majalah Tempo}

Selain menempati struktur arena di kelembagaan sastra (Horison, AJ, dan DKJ), GM juga menunggangi ruang yang lain yakni Tempo melalui rubrik Catatan Pinggir (Caping). Caping yang membentuk ciri khas seorang GM, tidak dapat dipisahkan hubungannya sebagai pendiri Tempo. Di samping itu, melalui hubungannya secara luas, GM menjalin relasi dengan berbagai pihak. Pada tahun 1994, sejumlah tulisan Caping diterjemahkan menjadi Sideliness: Thought Pieces from TEMPO Magazine oleh Jennifer Lindsay, konselor kebudayaan Kedutaan Besar Australia di Jakarta.

Maka, posisi GM di Tempo termasuk penting jika dikaitkan dengan perannya sebagai agen di arena sastra. Tempo menjadi salah satu struktur yang ditempati, telah memberikan GM dua modal sekaligus; simbolik melalui namanya yang dikenal sebagai sastrawan pendiri Tempo sekaligus penulis Caping, dan sosial kultural yang menghubungkan GM dengan banyak tokoh sehingga dapat membuka jalan untuk mendukung penyebaran karya-karyanya.

Goenawan Mohamad: Ikon Komunitas Utan Kayu (KUK)

Bersamaan dengan praktik sosial yang dilakukan di Tempo, pada tahun 1994, GM juga menempati struktur arena yang baru, yakni Komunitas Utan Kayu (KUK). Jika melihat dari kedudukan beberapa tokoh, seniman KUK menjalankan persebaran posisi ke berbagai media. Mereka menguasai rubrik-rubruk utama seni dan budaya, misalnya rubrik puisi Kompas yang 
dikelola Hasif Amini dan rubrik budaya Tempo oleh Nirwan Dewanto. Selain itu, jaringan TUK juga memegang peranan penting di pusat-pusat kebudayaan di Jakarta, salah satunya TIM. Bahkan, setelah GM, beberapa nama seniman KUK juga ikut duduk di kursi kepengurusan DKJ (Nugroho, 2012:96).

Maka, KUK dalam membentuk praktik sosial GM tidak berhenti sebatas sebagai pendiri saja, melainkan terus berlanjut pada serangkaian aktivitas di dalamnya. Pergulatan tersebut terimplementasi dalam berbagai kegiatan yang melibatkan GM sebagai sastrawan berpengaruh. Serangkaian praktik sosial GM di dalam komunitas ini semakin memperkuat citra GM sebagai ikon KUK dalam melegitimasi arena sastra Indonesia.

\section{Respons Struktur Arena terhadap Goenawan Mohamad}

Praktik sosial GM sebagai agen yang sejak awal ditunjukkan melalui berbagai aktivitas, mendatangkan timbal balik dari struktur arena baik berupa penerimaan, maupun penolakan yang melahirkan konflik serta kontradiksi.

Konflik tersebut ditunjukkan oleh GM melalui pergulatannya dengan seniman lain di arena sastra. GM sebagai seorang Manifestan pada dasarnya adalah seorang pemberontak karena pernyataan sikapnya telah membawa akibat bagi keberjalanan kariernya sebagai sastrawan saat itu. Arena sastra pun merespons tindakan GM melalui pembatasan karya di mana GM harus memakai nama samaran Sutisna Adji saat menerbitkan tulisan-tulisannya di media massa, sebagaimana Taufik Ismail dengan nama Nur Fajar (Media Indonesia, 1990).

Namun, humanisme universal yang sempat dinyatakan terlarang, kembali muncul melalui dominasi para sastrawannya di berbagai pusat kesenian yang berpengaruh. Hal ini berakibat pada pembalikan estetika di mana para sastrawan Manikebu menjalankan dominasi dengan strategi kekerasan simbolik terhadap kubu realisme sosialis. Berbagai usaha yang dilakukan salah satunya dengan "cara halus" yang tidak menampakkan serangan secara langsung, yaitu melalui pemuatan karya-karya yang membahas permasalahan seputar Pemberontakan '65.

Kesusastraan Indonesia pada tahun 1960-an tidak hanya diwarnai oleh Polemik Kebudayaan antara golongan Lekra dengan Manikebu, melainkan pada pertengahan tahun, terjadi pula perdebatan dalam bidang metode kritik sastra antara pengikut kritik sastra ilmiah (Kritik Analitik) dengan pengikut kritik sastra metode Ganzheit. Penolakan terhadap kritik sastra Analitik tersebut dilakukan oleh GM bersama Arief Budiman melalui tulisan-tulisannya yang mengemukakan gagasan metode Ganzheit sebagai pengganti kritik sastra Analitik.

Di samping itu, pada tahun ini, GM juga mengalami persinggungan dengan sastrawan lain dalam kasus Pengadilan Puisi-bentuk formal dari diskusi sastra yang diubah menjadi 
semacam pengadilan (Ismail dalam Pradopo, 2017:380). Pengadilan Puisi timbul akibat ketidakpuasan para sastrawan muda terhadap kehidupan sastra, khususnya puisi mutakhir pada awal tahun 1970-an. Pengadilan Puisi tidak lain merupakan salah satu kasus pemberontakan angkatan muda terhadap angkatan tua yang dianggap sudah mapan selama ini baik dalam bidang puisi maupun kritik sastra. Kasus Polemik Kritik Sastra dan Pengadilan Puisi tersebut termasuk pertarungan antaragen di mana masing-masing saling menggunakan modalnya untuk mengukuhkan kedudukan. GM berikut kiprahnya yang selalu diperhitungkan dalam setiap aktivitas sastra, semakin memperlihatkan dominasinya sebagai sastrawan yang berpengaruh di arena sastra Indonesia.

Sejumlah konflik yang telah dialami GM sebelumnya di dalam arena sastra Indonesia, muncul kembali dalam bentuk yang lain, yaitu adanya kontradiksi di Horison pada tahun 1993. Permasalahan yang muncul adalah perselisihan antara GM dengan Mochtar Lubis yang berkaitan dengan pengelolalan Horison. Selain terbagi menjadi dua kubu, yakni Horison lama dan Horison baru, akibat lain yang ditimbulkan dari perseteruan tersebut adalah terpecahnya pengurus Horison yang ditandai oleh keluarnya beberapa nama di antaranya Umar Kayam, Arif Budiman, Ali Audah, dan Sapardi Djoko Damono.

Respons lain dari struktur adalah penerimaan berwujud serangkaian aktivitas yang melambungkan eksistensi GM di arena sastra. Hal itu dapat dilihat melalui undangan bergengsi yang melibatkan GM, seperti Poetry International dan berbagai penghargaan, antara lain Anugerah Seni (1972), Profesor Teeuw Award (PTA) tahun 1992, dan Conscience and Integrity in Journalism (1997).

\section{Simpulan}

Berdasarkan pembahasan yang telah dilakukan terhadap praktik sosial GM di arena sastra Indonesia, diperoleh simpulan yang diuraikan sebagai berikut. GM menjalankan praktik sosial dengan menempati beberapa struktur arena, di antaranya Horison, AJ dan DKJ, Tempo melalui Caping, dan KUK. Rangkaian aktivitas GM saling terkait dan berhubungan satu sama lain. Sebelum GM menjadi bagian dari Horison, namanya sudah lebih dulu mencuat ke permukaan melalui keterlibatannya sebagai salah satu penandatangan naskah Manifes Kebudayaan yang pada masa Orde Lama dinyatakan terlarang.

Pada tahun 1994, peristiwa pembredelan Tempo menjadi tonggak permulaan GM dalam mendirikan Komunitas Utan Kayu (KUK). Serangkaian aktivitas GM tersebut tidak dapat berlangsung dengan sendirinya tanpa adanya timbal balik dari struktur sosialnya di arena sastra. Respons muncul dalam bentuk konflik, kontradiksi, maupun penerimaan GM sebagai agen yang 
namanya ikut dilambungkan. Wacana yang menyebut GM sebagai tokoh ikonik dalam beberapa struktur arena yang ditempatinya, tidak terlepas dari dominasi GM melalui praktik sosial yang telah dijalankannya sejak awal mula hingga tahun 1990-an.

\section{Daftar Pustaka}

Effendi, Anwar. 2005. "Simbol Waktu dalam Kumpulan Puisi Asmaradana Karya Goenawan Mohamad” dalam Jurnal Diksi Vol.12, No.2. Juli. Halaman 312-326.

Kompas. "Goenawan Mohamad dan Catatan Pinggirnya". 4 Agustus 1995.

Kratz, E. Ulrich. 2000. Sumber Terpilih Sejarah Sastra Indonesia Abad XX. Jakarta: Kepustakaan Populer Gramedia.

Mahanani, Rahwiku Titahwening. 2017. "Pencapaian Dewan Kesenian Jakarta (DKJ) dalam Arena Sastra pada Tahun 1990-an: Kajian Sosiologi Sastra Pierre Bordieu”. Skripsi: Universitas Sebelas Maret.

Media Indonesia. “Goenawan Mohamad Pembangkang dari Batang”. 17 Januari 1990.

Nugroho, Tri. 2012. "Dari Komunitas Utan Kayu ke Komunitas Salihara”. Disertasi: Universitas Indonesia.

Nurgiyantoro, Burhan. 1999. "Pengaktualan Unsur Mitologi dalam Puisi Goenawan Mohamad dan Sapardi Djoko Damono" dalam Jurnal Cakrawala Pendidikan Tahun XVIII, No. 4. November. Halaman 181-191.

Pradopo, Rachmat Djoko. 2017. Teori Kritik dan Penerapannya dalam Sastra Indonesia Modern Yogyakarta: Gajah Mada University Press.

Priyono, B. Herry. 2016. Anthony Giddens: Suatu Pengantar. Jakarta: Kepustakaan Populer Gramedia.

Rosidi, Ajip. 1968. Ikhtisar Sejarah Sastra Indonesia. Bandung: Bina Cipta.

1985. Kapankah Kesusastraan Indonesia Lahir?. Jakarta: Penerbit Gunung Agung.

Sambodja, Asep. 2010. Historiografi Sastra Indonesia 1960 an. Jakarta: Bukupop.

Sulistyo, Firman. 2018. "Praktik Kuasa-Wacana Dewan Kesenian Jakarta pada Era Reformasi: Kajian Kuasa dan Wacana Michel Foucault”. Skripsi: Universitas Sebelas Maret.

Sumardjo, Jakob. 1979. Masyarakat dan Sastra Indonesia. Yogyakarta: Nur Cahaya.

Susanto, Dwi. 2015. Kamus Istilah Sastra. Yogyakarya: Pustaka Pelajar.

Susanto, Dwi dan Rianna Wati. 2019. "Wacana Romantisme dalam Sejarah Sastra Indonesia Periode Kolonial Belanda (1900-1942)" dalam Jurnal KEMBARA Vol.5, No.1. April. Halaman 40-52.

Wibowo, Tri. 2012. Worlds Writers 354: Goenawan Mohamad. <https://www.kompasiana.com/mbahkanyout2/55179b4e813311aa669de991/worldswriters-354-goenawan-mohamad> (diakses tanggal 31 Juli 2019 pukul 23.55). 